\title{
Perubahan Bentuk Komoditi Unggulan Lokal Sebagai Alternatif Usaha di Desa Pringgarata
}

\author{
Suparmin*, Halimatus Sa'diyah, Anas Zaeni, Tajidan \\ Program Pascasarjana, Universitas Mataram, Mataram Indonesia \\ Jl. Majapahit No. 62 Mataram 82135, Indonesia
}

\section{Article history}

Received: 06-10-2020

Revised: $15-11-2020$

Accepted: 24-11-2020

*Corresponding Author:

Suparmin,

Program Pascasarjana

Universitas Mataram, Mataram

Nusa Tenggara Barat,

Indonesia

Email:

suparminjinem@gmail.com

\begin{abstract}
This community service activity was carried out in Pringgarata Village, Pringgarata District, Central Lombok Regency in August 2019. This community service activity uses field learning methods which are strengthened by demonstrations of local commodity development and assisted by experts processing soybeans into soy milk and dregs. soybeans become naget. Based on the results of community service activities regarding agro-industrial development based on local commodities, it can be concluded that: 1) The extension participants have given positive responses to all stages of the activity which is indicated by the seriousness of the participants in listening and discussing existing problems and participating actively in the demonstration of making agro-industry products, 2) In general, extension participants have acquired knowledge and skills in producing from agroindustry unit products, and 3) The next suggestion is to help increase household income at extension sites and at the same time encourage farmers to provide raw materials for agro-industrial development hence an active role from the government and related parties in policy makers is needed to implement a model of income generation program through community empowerment that has been carried out through activities outreach.
\end{abstract}

Keywords: commodity; superior; form; alternative; business

Abtrak: Kegiatan pengabdian pada masyarakat ini dilaksanakan di Desa Pringgarata, Kecamatan Pringgarata, Kabupaten Lombok Tengah pada bulan Agustus Tahun 2019. Kegiatan pengabdian pada masyarakat ini menggunakan metode pembelajaran dilapangan yang diperkuat dengan demonstrasi pengembangan komoditi lokal dan dibantu oleh tenaga ahli pengolah kedele menjadi susu kedele dan ampas kedele menjadi naget. Berdasarkan hasil kegiatan pengbadian pada masyarakat tentang pengembangan agroindustri yang berbasis pada komoditi lokal tersebut dapat disimpulkan bahwa: 1) Para peserta penyuluhan sudah memberikan tanggapan yang positif terhadap semua tahapan kegiatan yang ditunjukkan dengan keseriusan para peserta dalam menyimak dan mendiskusikan tentang permasalahan yang ada serta berpartisipasi aktif dalam demonstrasi pembuatan produk agroindustry, 2) Secara umum peserta penyuluhan telah memperoleh pengetahuan dan ketrampilan dalam memproduksi dari produk unit agroindustry, dan 3) Saran selanjutnya adalah untuk membantu meningkatkan pendapatan rumahtangga di lokasi penyuluhan dan sekaligus sebagai pendorong petani untuk menyediakan bahan baku pengembangan agroindustri, maka diperlukan peran aktif dari pemerintah dan pihak-pihak yang terkait dalam pengambil kebijakan untuk mengimplementasikan model program peningkatan 
pendapatan melalui pemberdayaan masyarakat yang telah dilakukan melalui kegiatan penyuluhan tersebut.

Kata Kunci: komoditi; unggulan; bentuk; alternatif, usaha

\section{PENDAHULUAN}

Pertambahan penduduk yang terus meningkat setiap tahunnya telah memberikan dampak yang sangat dahsyat terhadap masalah sosial ekonomi masyarakat, misalnya menurunya luas lahan pertanian yang dipergunakan untuk kebutuhan pemukiman penduduk, industri, dan lainnya, yang kemudian berdampak kepada ketahanan pangan masyarakat. Sebagai solusinya adalah pemerintah harus meningkatkan produksi pertanian untuk memenuhi kebutuhan pangan masyarakat.

Akhir-akhir ini, produksi pertanian terutama pangan telah mengalami peningkatan yang jauh lebih rendah dibandingkan dengan laju peningkatan jumlah penduduk. Hal ini disebabkan karena sampai saat ini produksi pertanian, terutama pertanian tanaman pangan, masih lebih ditekankan pada lahan-lahan basah. Sementara itu, ketersediaan lahan-lahan basah yang produksif untuk kepertluan produksi pertanian sudah makin berkurang sebagai akibat berlangsungnya alih-fungsi lahan dari lahan pertanian menjadi kawasan non pertanian seperti pemukiman dan industri.

Sementara itu, kawasan lahan pertanian yang tersedia masih belum dimanfaatkan secara optimal bagi pengembangan usaha produksi pertanian dan peternakan. Kawasan Nusa Tenggara Barat sendiri memiliki kawasan lahan pertanian sekitar $80 \%$ dari total luas lahan produksi yang ada. Demikian pula luas lahan untuk pertanian di Kabupaten Lombok Tengah hanya mencapai seluas 54.336 Ha pada tahun 2015, dan pada tahun 2014 lebih rendah yaitu 54.296 Ha. Di Kecamatan Pringgarata luas lahan sawah mencapai seluas 2.455 ha pada tahun (BPS Lombok Tengah, 2015). Dengan makin meningkatnya alih-fungsi lahan, yang lebih banyak menggerogoti lahan-lahan produktif, maka produksi pertanian harus diperluas ke lahan-lahan kering. Namun demikian, upaya pengembangan pertanian lahan basah atau lahan kering sampai saat masih belum meluas karena adanya kendala-kendala teknis maupun kendala sosial kemasyarakatan. Kendala teknik yang sering muncul adalah terbatasnya air yang menghalangi dilakukannya produksi pertanian dan peternakan secara memadai.

Keterbatasan sumberdaya yang ada di kawasan pertanian menciptakan kualitas sumberdaya yang rendah, hal ini ditunjukkan oleh rendahnya tingkat sosial ekonomi yang merupakan derivasi dari rendahnya produktifitas lahan. Produktifitas lahan yang rendah dan kualitas sumberdaya manusia yang rendah dapat menciptakan keterbatasan modal untuk berusahatani yang pada gilirannya akan menciptakan kemiskinan. Di Desa Pringgarata, produktifitas lahan untuk menghasilkan beberapa komoditi pertanian unggulan masih tergolong rendah. Menurut data yang dipublikasikan oleh Badan Pusat Statistik Kabupaten Lombok Tengah (2018) menjelaskan bahwa luas tanam untuk beberapa komoditi unggulan seperti padi sawh, jagung, kacang tanah, dan ubi kayu kecenderungannya meningkat dari tahun 2015 sampai dengan 2016, sementara luas tanam kedele dan ubi jalar kecenderungannya menurun. Luas panen padi sawah meningkat dari 5.167 han tahun 2015 menjadi 5.211 ha tahun 2016. Untuk Jagung meningkat dari 0 ha tahun 2015 menjadi 3 ha tahun 2016. Untuk komoditi kacang tanah meningkat dari 1.556 ha tahun 2015 menjadi 2.023 ha tahun 2016. Untuk komoditi ubi kayu naik dari 16 ha tahun 2015 menjadi 20 ha pada tahun 2016. Sedangkan untuk komoditi kedele menurun dari 323 ha pada tahun 2015 menjadi 98 han pada tahun 2016. Demikian pula untuk komoditi ubi jalar menurun dari 10 ha tahun 2015 menjadi 0 ha pada tahun 2016 . 
Komoditi-komoditi tersebut berpeluang sekali menjadi komoditi bahan baku untuk usaha-usaha kecil menengah di Desa Pringgarata.

Jumlah penduduk Kecamatan Pringgarata tahun 2017 mencapai 70.002 jiwa. Diantara desa yang ada di Kecamatan Pringgarata, desa Pringgarata merupakan wilayah yang memiliki jumlah penduduk yang paling tinggi yaitu sebanyak 9.115 jiwa dengan rata-rata jumlah anggota keluarga 4 orang. Disisi lain perkembangan jumlah industri kecil masih melambat. Potensi yang besar dalam membuka usaha yang produktif masih terbuka lebar bagi masyarakat di wilayah ini, dimana dengan adanya komoditi unggulan seperti kedelai dan kacang tanah untuk dimanfaatkan sebagai usaha kecil atau usaha rumahtangga yang dapat memberikan nilai tambah bagi komoditi tersebut dan juga dapat memberikan tambahan penghasilan bagi masyarakat.

Proses untuk menciptakan pendapatan yang lebih tinggi dan sekaligus mengentaskan kemiskinan memerlukan waktu yang panjang dan pemilihan kegiatan-kegiatan yang produktif yang bersumber dari sumberdaya lokal. Berdasarkan data yang tersedia, maka diketahui potensi dasar untuk pengembangan masyarakat di Desa Pringgarata dan sekaligus untuk mengentaskan kemiskinannya. Hal ini dapat dilakukan melalui pengembangan potensi sistem agribisnis. Potensi yang ada dapat berupa tersedianya tenaga kerja keluarga, potensi lahan untuk usaha tani tanaman semusim, potensi komoditas unggulan seperti kacang tanah, kedele, untuk pengembangan agroindustri sehingga dapat menghasilkan nilai tambah yang signifikan dalam rangka meningkatkan pendapatan masyarakat.

Berbagai program pengentasan kemiskinan yang telah diintroduksi pemerintah diantaranya adalah Instruksi Presiden mengenai Desa Tertinggal, Proyek Peningkatan Pendapatan Petani-Nelayan Kecil dan Program Pengembangan Kecamatan bersifat top-down dan mengabaikan potensi niali-nilai local yang selama ini mendukung penghidupan masyarakat. Masa adopsi program sangat singkat sehingga tidak berfungsi mengatasi masalah kemiskinan (Sumodiningrat, Santosa dan Maiwan, 1999).

Upaya penanggulangan kemiskinan menurut Kartasasmita (1996) dilakukan dengan memberdayakan masyarakat miskin oleh mereka sendiri melalui proses pendidikan berkelanjutan dengan prinsip menolong diri sendiri melalui kemampuan. Pelaksanaannya berlandaskan kemampuan dalam meningkatkan pendapatan agar lebih menjangkau sumberdaya, permodalan, teknologi dan pasar.

Agroindustri merupakan salah satu sektor industri yang mempunyai nilai strategis untuk dikembangkan sebagai suatu usaha yang dapat menciptakan peluang, baik untuk lapangan kerja maupun peluang berusaha bagi masyarakat khususnya masyarakat perdesaan. Sehingga diharapkan dapat mengurangi jumlah pengangguran, pendayagunaan sember daya, peningkatan pendapatan dan kesejahteraan masyarkat. Dalam hal ini, dapat dilihat bahwa kegiatan ini akan memperbaiki kelemahan-kelamahan yang ada pada komoditi pertanian seperti halnya mudah rusak, kuantitas dan kualitas beragam, bersifat musiman, dan tersebar pada lokasi yang sulit dijangkau oleh konsumen (Giyatmi,2005).

Agroindustri memiliki keterkaitan (linkages) yang besar, baik dari hulu hingga ke hilir. Agroindustri pengolahan yang menggunakan bahan baku hasil pertanian memiliki keterkaitan yang kuat dengan kegiatan budi daya pertanian maupun dengan kegiatan industri lainnya. Seiring dengan meningkatnya hasil pertanian NTB dalam arti luas, baik itu produk hasil tanaman pangan dan hortikultura, perkebunan, maupun perairan dan perikanan, membuat industry pengolahan sangat potensial untuk dikembangkan (Dwi,2016). 
Agroindustri sebagai motor penggerek pembangunan pertanian diharapkan akan dapat memainkan peranan penting dalam kegiatan pembangunan daerah baik dalam sasaran pemerataan pembangunan, pertumbuhan ekonomi maupun stabilitas nasional. Oleh karena itu, pertumbuhan agroindustri perlu diarahkan kewilayah pedesaan mengingat jenis industry pertanian yang dapat dikembangkan sangat banyak, sehingga mampu menangkap efek ganda bagi kepentingan pembangunan nasional, pedesaan dan perekonomian daerah (Soekartawi, 2011).

Pengembangan kegiatan industri pertanian (agroindustri) dewasa ini sudah berkembang cukup baik, baik dari segi jumlah maupun jenisnya. Perubahan bentuk suatu komoditi pertanian dari bahan baku menjadi barang jadi memerlukan waktu dan ketrampilan yang cukup guna memperoleh hasil yang baik. Perubahan bentuk ini melalui suatu proses yang relatif panjang, sehingga hal ini dapat dikelompokkan dalam suatu subsistem agribisnis yaitu agroindustri. Adapun agroindustri yang sudah berkembang seperti agroindustri tahu tempe, agroindustri kripik (seperti kripik pisang, ubi, nangka, dan lain-lain), agroindustri dodol rumput laut, manisan rumput laut, agroindustri bandeng presto, dan lain-lain, serta agroindustri yang tidak umum lagi dan belum banyak diusahakan yaitu agroindustry susu kedele dan naget kedele.

Tujuan dari kegiatan penyuluhan ini adalah meningkatkan pengetahuan masyarakat petani dan masyarakat lainnya di Desa Pringgarata dalam berbagai kegiatan antara lain, pertama, untuk menggali potensi produktif sistem agribisnis dan potensi keluarga untuk mengambangkan agroindustry berbasis komoditi local dalam rangka mengentaskan kemiskinan. Kedua, memberikan Berbagai alternatif pengembangan agroindustri berbasis komoditi lokal bernilai ekonomi tinggi.

\section{METODE}

Kegiatan pengabdian pada masyarakat ini dilaksanakan di Desa Pringgarata, Kecamatan Pringgarata, Kabupaten Lombok Tengah pada bulan Agustus Tahun 2019. Penetapan lokasi tersebut dilakukan secara sengaja (purposive sampling). Khayalak sasaran dalam penyuluhan ini adalah masyarakat di lokasi kegiatan penyuluhan. Karena masyarakat di desa ini sangat berminat terhadap kegiatan penyuluhan yang dilaksanakan dalam rangka meningkatkan pengetahuan mereka.

Kegiatan pengabdian pada masyarakat ini menggunakan metode pembelajaran di lapangan yang diperkuat dengan demonstrasi pengembangan komoditi lokal dan dibantu oleh tenaga ahli pengolah kedele menjadi susu kedele dan ampas kedele menjadi naget. Guna menunjang pencapaian tujuan penyuluhan, pemilihan metode penyuluhan yang relevan dan efektif sangat penting. Dalam penyampaian materi penyuluhan ini, Tim Penyuluh telah memilih dan menggunakan metode ceramah dan diskusi yang dikombinasikan dengan metode pembelajaran di lapang yang diperkuat dengan demonstrasi pengembangan berbagai produk berbasis komoditi lokal dengan dibantu para pelaku agroindustri sukses yang relevan. Untuk membantu peserta penyuluhan agar mudah memahami dan menyerap materi yang disuluhkan digunakan juga alat-alat peraga.

Materi penyuluhan ini terdiri atas 3 pokok bahasan dan setiap pokok bahasan disampaikan oleh seorang anggota Tim Penyuluh secara bergantian. Materi tersebut antara lain: 1) Potensi sistem agribisnis pendukung pengembangan agroindustri berbasis komoditi lokal untuk pengentasan kemiskinan, 2) Manajemen permodalan untuk mendukung pengembangan agroindustri berbasis komoditi local, 3) Analisis pendapatan dan efisiensi ekonomi agroindustri berbasis komoditi lokal

Setelah materi penyuluhan disampaikan oleh Tim Penyuluh, dilanjutkan dengan diskusi/tanya jawab dengan peserta. Dalam diskusi/tanya jawab tersebut, Tim penyuluh 
menampung/mencatat semua pertanyaan yang diajukan oleh peserta tentang strategi pemasaran dan kendala dalam pemasaran produk pertanian. Selanjutnya Tim Penyuluh memberikan jawaban atas segala pertanyaan tersebut, sehingga peserta mengerti dan merasa puas. Jawaban yang diberikan oleh Tim Penyuluh diharapkan dapat dijadikan pedoman oleh kelompok masyarakat dan petani dalam mengembangkan system Agribisnis.

Pada akhir acara penyuluhan tim penyuluh mengajukan beberapa pertanyaan kepada peserta dengan maksud untuk mengetahui sejauh mana materi-materi yang telah disampaikan dapat dimengerti dan dipahami oleh peserta penyuluhan.

\section{HASIL DAN PEMBAHASAN}

\section{Realisasi Pemecahan Masalah}

Kegiatan pengabdian pada masyarakat ini merupakan implementasi dari hasil tinjauan kondisi wilayah di Kecamatan Pringgarata Lombok Tengah yang memiliki potensi produksi komoditi yang menjamin untuk dikembangkannya agroindustri dalam rangka mengentaskan kemiskinan di Desa Pringgarata. Tujuan implementasi model ini adalah terpautnya pola produksi antar subsistem agribisnis lahan kering sehingga produktivitas teknis-ekonomisnya menjadi berjalan melalui penciptaan nilai tambah agroindustri berbasis komoditi lokal. Komoditi lokal yang tersedia cukup besar untuk menjamin tumbuh kembangnya agroindutri di desa Pringgarata ini adalah komoditi kedele. Komoditi kedele ini menjadi basis pengembangan model pengentasan kemiskinan agar diperoleh nilai tambah dari hasil olahan kedele menjadi susu kedele dan naget ampas kedele.

Realisasi pemecahan masalah kegiatan pengabdian pada masyarakat ini memerlukan kerjasama antara pihak penggagas (Tim penyuluh) dengan aparat desa dan masyarakat setempat. Pekerjaan dimulai dari perencanaan, pelaksanaan, dan evaluasi. Strategi kegiatan penyuluhan dilakukan dengan melibatkan anggota keluarga usia produktif sehingga dapat berperan dalam kegiatan pengentasan kemiskinan tersebut.

Rincian strategi kegiatan penyuluhan untuk pengembangan model pengentasan kemiskinan di desa Kediri adalah:

1. Tahap penyadaran masyarakat merupakan tahap penentu keberhasilan pengembangan model karena bertujuan menciptakan kesadaran, memotivasi masyarakat agar produktif dan berwawasan lingkungan.

2. Pembentukan kelompok kerja yang beranggotakan rumah tangga di desa setempat dengan tujuan untuk menyebarluaskan adopsi model ke sekitar desa Pringgarata

3. Peningkatan kapasitas pelaksanaan penyuluhan meliputi kegiatan:

a. Kegiatan pelatihan, diskusi tentang permasalahan yang dihadapi berkaitan dengan persiapan dan pelaksanaan kegiatan penyuluhan

b. Pengenalan teknologi produksi produk olahan kedele dan demonstrasi pengembangan agroindustri susu kedele dan kerupuk tempe.

c. Latihan penerapan analisis usaha serta manajemen pemasaran yang menguntungkan

Pada Gambar 1. Tim penyuluh memberikan materi penyuluhan, dan para peserta penyuluhan sedang mendengarkan materi penyuluhan yang disampaikan oleh tim penyuluh dengan tekun. Selain itu peserta penyuluhan mengikuti demonstrasi pembuatan susu kedele dan naget ampas kedele. Dalam kegiatan ini kami mengundang ahli membuat susu kedele dan naget untuk. Kami dan ahli menjelaskan cara membuatnya kemudian peserta penyuluhan ikut mempraktekkan cara membuat susu kedele dan 
naget ampas kedele. Para peserta sangat antusias ingin mengetahui cara pembuatan susu kedele dan naget kedele, mereka bergantian membuatnya, sehingga dalam waktu singkat mereka sudah mendapatkan pengetahuan yang sangat berguna untuk mengembangkan potensi sumberdaya lokal dan potensi diri, sehingga sangat bermanfaat bagi kehidupan mereka.


Gambar 1. Kegiatan Penyuluhan pada Pemberian Materi dan Demonstrasi di Desa Pringgarata

1. Staf desa dan Pemateri sedang menjelaskan materi penyuluhan

2. Peserta penyuluhan sedang mendengarkan materi penyuluhan

3. Peserta penyuluhan praktek membuat susu kedele

4. Peserta penyuluhan praktek membuat naget ampas kedele

\section{Hasil Kegiatan}

Berdasarkan hasil pemantauan dan pengamatan tentang pentingnya pengetahuan dan keterampilan dalam penggunaan dan pemanfaatan sumberdaya lokal untuk usaha sampingan masyarakat melalui kegiatan pengbadian tersebut, maka dapat disimpulkan bahwa kegiatan penyuluhan ini cukup berhasil. Dalam penjelasan berikut ini dapat dirincikan beberapa keberhasilan dalam pengabdian pada masyarakat ini yaitu:

Pertama, adanya kesadaran masyarakat tentang pendapatan yang diperoleh dari kegiatan usaha yang masih rendah sehingga menyebabkan kesejahteraan mereka menjadi rendah. Oleh karena itu diperlukan usaha peningkatan pendapatan melalui kegiatan lain seperti membuat susu kedele atau naget ampas kedele dengan menggunakan sumberdaya lokal yang tersedia. Sebagian besar petani, buruh tani, dan masyarakat pada umumnya di desa Pringgarata masih berpengahsilan rendah. 
Pengetahuan yang diperoleh dari penyuluhan ini menyadarkan mereka bahwa betapa pentingnya usaha sampingan dilakukan. Jika ini dapat dilakukan akan dapat menambah penghasilan keluarga.

Kedua, bertambahnya pengetahuan dan keterampilan masyarakat tentang potensi produksi pertanian terutama komoditi unggulan lokal (kedele) untuk pengembangan agroindustri yang bernilai ekonomi tinggi. Kesadaran akan pentingnya pemanfatan sumberdaya lokal seperti komoditi kedele untuk usaha, maka ini memberikan keuntungan karena usaha agroindustri ini memiliki nilai tambah yang lebih tinggi. Disamping itu sebagai bahan baku yang tersedia di tempat sendiri akan mengurangi biaya produksi bagi usaha agroindustri tersebut.

Ketiga, bertambahnya kesadaran masyarakat tentang perbaikan pendapatan dan sekaligus kesejahteraan mereka melalui pengembangan agroindustri komoditi unggulan lokal. Setiap individu yang telah dewasa akan menyadari betapa pentingnya pendapatan yang diperoleh dari hasil kegiatan usahanya. Pemanfatan waktu luang yang sebesar-besarnya untuk kegiatan produktif akan membawa penghasilan yang lebih besar. Untuk itu kesadaran yang telah timbul dikalangan masyarakat ini perlu mendapat perhatian dari pemerintah setempat melalui BUMDES untuk terus membina kelompokkelompok masyarakat yang ingin memperbaiki pendapatannya melalui kegiatan-kegiatan yang produktif.

Keempat, adanya peluang usaha bagi masyarakat di lokasi penyuluhan untuk membuka usaha sebagai perajin dan atau pedagang produk hasil agroindustri. Pengembangan usaha kecil mikro yang banyak terdapat di pedesaan perlu mendapat perhatian dari pemerintah. Tidak sia-sia bagi pemerintah yang telah mengucurkan anggaran pembangunan pedesaan yang begitu besar, jika dimanfaatkan untuk mengembangkan usaha-usaha mikro pedesaan. Peluang ini tentunya cukup besar untuk mengembangkan usaha agroindustri pedesaan seperti usaha pembuatan susu kedele dan naget ampas kedele.

Kelima, memotivasi masyarakat untuk memproduksi produk pertanian yang memiliki nilai ekonomi tinggi seperti kedele dalam rangka memenuhi kebutuhan bahan baku bagi pengembangan agroindustri di lokasi penyuluhan. Kesadaran setiap individu untuk melakukan pekerjaan tidak semata-mata hanya timbul dari dalam individu itu sendiri, namun juga berasal dari faktor eksternal individu tersebut. Misalnya saja seseorang yang mendengar informasi dari penyuluh tentang betapa pentingnya membuat usaha dengan modal kecil dan terjangkau. Maka penyuluh berperan sebagai motivator untuk mengerakkan keinginan seseorang untuk berbuat. Hal inilah yang membuat peserta penyuluhan termotivasi untuk mencoba melakukan kegiatan usaha yang bermodal kecil tersebut.

\section{Evaluasi Kegiatan}

Berdasarkan hasil pengamatan Tim Penyuluh pada tahap penyadaran, pembentukan kelompok, dan penyampaian materi serta domonstrasi pembuatannya, dapat dikatakan cukup berhasil. Hal ini dapat dilihat dari diskusi yang aktif dimana peserta atau masyarakat sangat antusias dan aktif bertanya tentang materi yang disuluhkan. Demikian pula dalam demostrasi masyarakat sangat berperan aktif dalam membersihkan bahan baku yang akan digunakan dan keterlibatannya dalam membuat susu kedele maupun naget ampas kedele.

Faktor pendorong dari keberhasilan penyuluhan tersebut adalah adanya informasi yang penting bagi peningkatan pengetahuan dan keterampilan mereka. Kedua adanya demonstrasi pembuatan produk agroindustri yang belum pernah mereka lakukan yaitu pembuatan susu kedele dan naget ampas kedele. Sementara itu yang menjadi faktor penghambat dalam pembinaan lebih lanjut adalah dana. Hal ini berimplikasi pada waktu yang terbatas sehingga hasil penyuluhan belum optimal. 


\section{KESIMPULAN DAN SARAN}

\section{Kesimpulan}

Berdasarkan hasil kegiatan pengbadian pada masyarakat tentang pengembangan agroindustri yang berbasis pada komoditi lokal tersebut dapat disimpulkan bahwa: pertama, Para peserta penyuluhan sudah memberikan tanggapan yang positif terhadap semua tahapan kegiatan yang ditunjukkan dengan keseriusan para peserta dalam menyimak dan mendiskusikan tentang permasalahan yang ada serta berpartisipasi aktif dalam demonstrasi pembuatan produk agroindustry. Kedua, secara umum peserta penyuluhan telah memperoleh pengetahuan dan ketrampilan dalam memproduksi dari produk unit agroindustri

\section{Saran}

Untuk membantu meningkatkan pendapatan rumahtangga di lokasi penyuluhan dan sekaligus sebagai pendorong petani untuk menyediakan bahan baku pengembangan agroindustri, maka diperlukan peran aktif dari pemerintah dan pihak-pihak yang terkait dalam pengambil kebijakan untuk mengimplementasikan model program peningkatan pendapatan melalui pemberdayaan masyarakat yang telah dilakukan melalui kegiatan penyuluhan tersebut.

\section{Ucapan Terima Kasih}

Terimakasih disampaikan kepada para peserta yang telah meluangkan waktunya untuk hadir dan membaca materi yang telah disebarkan dan bersedia mengikuti demonstrasi dn praktek langsung serta mengikuti tahap evaluasi awal dan evaluasi akhir. Terimakasih pula disampaikan kepada redaksi dan reviuwer yang telah berkenan menerbitkan artikel ini pada Jurnal GemaNgabdi.

\section{DAFTAR PUSTAKA}

Badan Pusat Statistik Kabupaten Lombok Tengah, 2017. Lombok Tengah Dalam Angka. Badan Pusat Statistik Kabupaten Lombok Tengah. Praya

Badan Pusat Statistik Kabupaten Lombok Tengah, 2015. Pringgarata Dalam Angka. Badan Pusat Statistik Kecamatan Pringgarata. Pringgarata

Dwi O. 2016. Analisis Nilai Tambah Produk Agroindustri Berbasis Ikan Di Kota Mataram.

Giyatmi, 2015. Sistem Pembangunan Agroindustri Perikanan Laut Suatu Kajian Kelayakan Dan Strategi Pengembangan Di Provinsi Jawa

Kartasasmita, G. 1996. Pemberdayaan Masyarakat: Konsep Pembangunan Yang Berakar Pada Masyarakat. Badan Perencanaa Pembangunan Nasional. Jakarta

Soekartawi, 2011. Agroindustri Dalam Perspektif Sosial Ekonomi. PT. Raja Grafindo Persada. Jakarta

Sumodiningrat, Santoso B, Maiwan M. 1999. Kemiskinan: Teori, Fakta dan Kebijakan. Penerbit

IMPAC. Jakarta. 